\title{
Az akut myocardialis infarctus fóbb hazai ellátási jellemzői 2005-2009 között a EuroHOPE kutatás eredményei alapján
}

\author{
Belicza Éva dr. ${ }^{1}$. Lám Judit dr. ${ }^{1}$ - Kósa István dr. ${ }^{2,3}$ \\ ${ }^{1}$ Semmelweis Egyetem, Egészségügyi Menedzserképző Központ, Budapest \\ ${ }^{2}$ Honvédkórház Kardiológia Rehabilitációs Intézete, Balatonfüred \\ ${ }^{3}$ Szegedi Tudományegyetem, Általános Orvostudományi Kar, Orvosi Rehabilitációs és Fizikális Medicina Tanszék, \\ Szeged
}

Bevezetés: A EuroHOPE kutatás az ellátás elemzésének standardizált módszereit fejlesztette ki. Célkitüzés: A szerzők célul tűzték ki a hazai akut myocardialis infarctus ellátásának elemzését és a közremúködő országok adataival való összevetését. Módszer: A korai és kései invazív kardiológiai beavatkozások alkalmazását, a gyógyszerek kiváltását és a halálozást elemezték. Az eredményeket finn, norvég, olasz, skót és svéd adatokkal vetették össze. Eredmények: Nemzetközileg is kedvező eredmény, hogy az időszak végére a betegek közel fele részesült korai intervencióban, 90\% körüli volt a statinok, az angiotenzinkonvertálóenzim-gátlók és angiotenzinreceptor-blokkolók kiváltása. Nem magyarázhatóan csökkent a béta-blokkolók alkalmazása. A halálozás javult, de a többi országénál lényegesen kedvezőtlenebb volt. Az egyéves halálozás a korai intervenciós csoportban másfélszerese, a késeiben több mint kétszerese volt az utána következő legrosszabb értéknek. Következtetések: Javasolt az okok vizsgálata a teljes követési időszakban a szakmai tevékenységre és a múködési gyakorlatra, illetve a betegek szerepére vonatkozóan. Szükséges a trendek követése és az ST- és nem ST-elevációs myocardialis infarctus kórformák elkülönítő kódolása a mélyebb elemzések elősegítésére. Orv. Hetil., 2016, 157(41), 1626-1634.

Kulcsszavak: myocardialis infarctus, gyógyszeralkalmazás, halálozás

\section{Main characteristics of the care of acute myocardial infarction in Hungary between 2005-2009, based on the results of the EuroHOPE research}

\begin{abstract}
Introduction: The EuroHOPE research developed the standardised methodology of the analysis of the healthcare process. Aim: The aims of the authors were to analyze the care of acute myocardial infarction in Hungary and to compare the results to those of the partner countries. Method: The authors analyzed the application of early and late invasive interventions, medication purchase, and mortality. The results were compared to Finnish, Norwegian, Italian, Scottish and Swedish data. Results: By the end of the observed period, approximately half of the patients received early treatment, which is an internationally acceptable result. Purchase of statins, angiotensin converting enzyme inhibitors, and angiotensin receptor blockers was around 90\%, but the application of beta-blockers has decreased for unknown reason. The mortality rate has improved, but it was still significantly worse than that in the partnering countries. One year mortality in the early intervention group was 1.5 times higher, and in the late intervention group was 2 times higher than the second worst results. Conclusions: The causal analysis concerning the professional activities, operational practices, and the role of the patients in the observed period is highly recommended. For more detailed analysis it is necessary to follow the trends and to separate the diagnoses of ST- elevation and non-ST-elevation acute myocardial infarction.
\end{abstract}

Keywords: myocardial infarction, medication, mortality

Belicza, É., Lám, J., Kósa, I. [Main characteristics of the care of acute myocardial infarction in Hungary between 2005-2009, based on the results of the EuroHOPE research]. Orv. Hetil., 2016, 157(41), 1626-1634.

(Beérkezett: 2016. július 11.; elfogadva: 2016. augusztus 11.) 


\section{Rövidítések}

$\mathrm{ACE}=$ angiotenzinkonvertáló enzim; $\mathrm{AMI}=$ akut myocardialis infarctus; $\mathrm{ARB}=$ angiotenzinreceptor-blokkoló; $\mathrm{CABG}=\mathrm{cO}-$ ronaria-bypassmútét; EuroHOPE = European Health Care Outcomes, Performance and Efficiency; OEP = Országos Egészségbiztosítási Pénztár; PCI = percutan coronariaintervenció; taj = társadalombiztosítási azonosítójel

Az egészségügyi ellátás egyik kiemelt jelentőségű területe az akut myocardialis infarctusban (AMI-ban) szenvedők ellátása. Mind az eredményesség, mind a hatékonyság szempontjából alapvető az időben történő, hatásos terápiák nyújtása, amit bizonyítékokra támaszkodó szakmai irányelvek támogatnak $[1,2]$.

Az elmúlt években több publikáció jelent meg a hospitalizált AMI incidenciájáról, a kezelés jellemzőiről, illetve a kimenetekről [3-6]. Az ezekben a közleményekben ismertetett folyamat- és eredményindikátor-értékek azonban nem alkalmasak arra, hogy a trendeket, országok ellátási gyakorlatát, illetve az elért eredményeket összevessük, mivel az adatforrások, a bevonási és kizárási kritériumok, elemzési módszerek egymástól eltérőek.

A European Health Care Outcomes, Performance and Efficiency (EuroHOPE) kutatás reguláris adatgyưjtésekre támaszkodva, úgynevezett adminisztratív adatok felhasználásával, standardizált módszerekkel dolgozott ki indikátorokat. Ezek lehetővé teszik egy-egy ország ellátásának jellemzését és összevetését a kutatásban részt vevő más országok eredményeivel. Munkánk célja, hogy e kutatás eredményeire támaszkodva elemezzük a hazai AMI-ellátást, összevessük a nemzetközi eredményekkel és az eredmények alapján ajánlásokat fogalmazzunk meg a szükséges teendőkre.

\section{Módszer}

A 2005-2009 közötti időszakban a heveny vagy ismétlődő szívizomelhalás (BNO: I21, I22) ápolási fődiagnózissal akut osztályra felvettek közül azokat a 40-84 éves betegeket vontuk be, akiknek a megelőző 365 nap során nem volt ismert AMI miatti ellátása. Az így definiált osztályos felvételek jelentették az úgynevezett indexfelvételeket. Kizártuk az elemzésből a külföldi állampolgárokat és az érvényes taj-szám nélküli betegeket.

A hazai adatok az Országos Egészségbiztosítási Pénztár (OEP) által gyűjtött és az Egészségügyi Stratégiai Kutatóintézet számára átadott adatbázisokból származnak. Az elemzett egyedi rekordok az úgynevezett pszeudo társadalombiztosítási azonosítójelek (taj) alkalmazásával a betegek azonosítását nem teszik lehetővé, de az ellátási események összekapcsolhatók, így a betegek követése és az ellátás eredményei megismerhetővé válnak.

A gyógyszerekre vonatkozó információ a vényadatbázisból származik, amely a receptre kiváltott gyógyszereket és a kiváltás időpontját is tartalmazza. Mivel számunkra csak a kiváltás hónapja állt rendelkezésre, ezért időpontként elméleti értékként az adott hónap 15. napját tekintettük. Nem vizsgáltuk a kiváltások számát és a gyógyszerek dózisát.

A másodlagos betegségekre (komorbiditásra) két forrásból nyertünk adatokat. Egyrészt felmértük a megelőző 365 nap kórházi felvételei során rögzített valamennyi diagnózist, illetve figyelembe vettük a specifikusan ezen diagnózisokra kiváltott gyógyszereket. Ezek részletes bemutatását ugyanezen lapszám módszertani cikke tartalmazza.

A korai szívkatéteres tágításon (PCI), illetve coronaria-bypassmütéten $(\mathrm{CABG})$ átesettek arányát a felvétel napján és az azt követő napon végzett beavatkozások alapján számoltuk. A betegeket egy éven keresztül követtük. Amennyiben a beteg nem részesült korai intervencióban, de a követési időszakban átesett valamelyik beavatkozáson, akkor a késői kezelésben részesültek csoportjába került besorolásra. Az alkalmazott beavatkozáskódokat az 1. táblázat tartalmazza.

A nemzetközi irányelvekben [1,2] szereplő gyógyszerek közül a vényköteles béta-blokkolók, statinok és az ACE-gátlók, illetve angiotenzinreceptor-blokkolók (ARB) (2. táblázat) alkalmazását tudtuk elemezni. A kezelés szempontjából fontos acetilszalicilsav nem vényköteles, így alkalmazásáról nincs elérhető betegszintú adat, feldolgozásunkban ezért nem szerepel. Az említett három hatóanyagcsoportban vizsgáltuk az adott gyógyszert legalább egyszer kiváltók arányát azon betegek körében, akik legalább 90, illetve 365 nappal az indexfelvételt követően életben voltak. Az elemzéseket aszerint is elvégeztük, hogy az indexfelvételt megelőző időszakban történt-e ezen hatóanyagcsoportokban gyógyszerkiváltás.

A halálozás időpontját a Központi Népesség-nyilvántartó adataira támaszkodó OEP hivatalos taj-állománya alapján határoztuk meg. Nem vizsgáltuk a halál okát és helyét.

1. táblázat | A PCI- és CABG-eljárások figyelembe vett kódjai

\section{Szívkatéteres tágítás (PCI)}

01100, 33970, 33971, 33972, 53963, 53966, 01344, 33974, $33975,33976,33981,33982,33983,33984,33985,33986$, 33987, 33988, 33989, 3398A, 01339

Coronaria-bypassmútét (CABG)

53611, 53612, 53613, 53614, 53615, 53616, 53617

2. táblázat | A kiváltott gyógyszerek ATC-kódjai

\begin{tabular}{ll}
\hline Gyógyszer neve & ATC-kód \\
\hline Béta-blokkolók & $\mathrm{C} 07^{*}$ \\
ACE-gátlók & $\mathrm{C} 09 A^{*}, \mathrm{C} 09 \mathrm{~B}^{*}$ \\
$\begin{array}{l}\text { Angiotenzinreceptor-blokkolók } \\
\text { (AT-II-antagonisták) (ARB) }\end{array}$ & $\mathrm{C} 09 \mathrm{C}^{*}, \mathrm{C} 09 \mathrm{D}^{*}$ \\
Statinok & \\
\hline
\end{tabular}

* A kód többi karaktere bármi lehet. 
3. táblázat $\mid$ Az AMI-ellátás legfontosabb adatai a EuroHOPE kutatás országaiban

\begin{tabular}{|c|c|c|c|c|c|c|c|c|c|c|}
\hline \multirow[t]{2}{*}{ Ország $^{+}$} & \multirow[t]{2}{*}{ Év } & \multirow[t]{2}{*}{$\begin{array}{l}\text { Esetszám } \\
\text { (fö) }\end{array}$} & \multirow{2}{*}{$\begin{array}{l}\text { Férfiak } \\
\text { aránya } \\
(\%)\end{array}$} & \multirow[t]{2}{*}{$\begin{array}{l}\text { Átlagéletkor } \\
\text { (év) }\end{array}$} & \multicolumn{2}{|c|}{$\begin{array}{l}2 \text { napon belül } \\
\text { PCI-kezeltek (\%) }\end{array}$} & \multirow{2}{*}{$\begin{array}{l}2 \text { napon túl PCI- vagy } \\
\text { CABG-beavatkozás- } \\
\text { ban részesültek (\%) } \\
\text { Nyers }\end{array}$} & \multicolumn{3}{|c|}{ Halálozási arányszám (\%)* * } \\
\hline & & & & & Nyers & Korrigált* & & 30 napos & 90 napos & 365 napos \\
\hline HUN & 2005 & 13403 & $57,3 \%$ & 66,4 & 25,2 & 24,0 & 18,2 & 21,2 & 24,7 & 31,7 \\
\hline HUN & 2006 & 13363 & $57,8 \%$ & 66,2 & 33,5 & 31,6 & 17,3 & 20,9 & 23,6 & 30,6 \\
\hline HUN & 2007 & 12661 & $57,4 \%$ & 66,0 & 41,4 & 38,9 & 14,8 & 20,1 & 23,2 & 30,1 \\
\hline HUN & 2008 & 12617 & $58,2 \%$ & 65,9 & 46,6 & 43,7 & 12,9 & 19,4 & 22,9 & 30,7 \\
\hline HUN & 2009 & 12719 & $59,3 \%$ & 66,0 & 49,7 & 46,7 & 11,3 & 18,8 & 22,3 & 29,9 \\
\hline FIN & 2008 & 7175 & $65,2 \%$ & 69,1 & 34,6 & 35,7 & 17,4 & 11,8 & 14,2 & 19,7 \\
\hline ITA & 2008 & 8419 & $69,1 \%$ & 67,4 & 39,0 & 37,9 & 25,4 & 8,1 & 10,3 & 15,5 \\
\hline NOR & 2009 & 8127 & $68,5 \%$ & 67,3 & 38,6 & 37,4 & 20,8 & 5,8 & 7,6 & 12,4 \\
\hline SCO & 2008 & 6817 & $66,3 \%$ & 66,5 & 23,6 & 22,4 & 24,0 & 13,4 & 16,4 & 22,5 \\
\hline SWE & 2008 & 17320 & $65,4 \%$ & 69,4 & 45,7 & 47,6 & 13,6 & 7,8 & 9,7 & 14,9 \\
\hline
\end{tabular}

+ FIN = Finnország; HUN = Magyarország; ITA = Olaszország (Torino és Lazio tartomány); NOR = Norvégia; SCO = Skócia; SWE = Svédország.

* Kor és nem szerint kiegyenlített.

**Kor, nem, komorbiditás, megelőző kórházi ápolási idő szerint kiegyenlített.

A kockázatokra történő kiegyenlítést többváltozós logisztikus regresszióval végeztük. A hazai elemzéseknél standard alapként a magyar betegek jellemzőit vettük figyelembe. Független változók a nem, kor, gyógyszerkiváltással figyelembe vett komorbiditás és a megelőző évben kórházban töltött idő voltak. A számításokat SPSS szoftverrel végeztük.

A nemzetközi összehasonlításban a EuroHOPE-országok közül Magyarország mellett Finnország, Olaszországból Torino és Lazio tartomány, Norvégia, Skócia és Svédország szerepelnek. Az összehasonlítás éve Norvégia esetén 2009 , a többi ország vonatkozásában 2008 volt. A gyógyszerkiváltásokat a 2006-2008 közötti időszakban hasonlítottuk össze. Ebben Skócia adathiány miatt nem szerepel. A halálozások kockázatra történő kiegyenlítését a konzorciumot vezetó finn kutatócsoport által kidolgozott Stata szoftverhez készített feldolgozóprogramokkal végeztük. A standard alapot a finn AMIbetegpopuláció jellemzői szolgáltatták. A kiegyenlítő eljárás során a bemeneti változók a nem, a kor, a komorbiditás, illetve a megelőző évben kórházban töltött idő voltak.

\section{Eredmények}

Magyarországon az elemzésbe bevont 40-84 éves, AMI miatt hospitalizált betegek száma a 2005-2006-os 13,4 ezer körüli értékról az időszak második felére 600-700 fövel csökkent. Némi növekedés volt megfigyelhető a férfiak részarányában. A betegek átlagéletkora 65,9-66,4 év között volt. A két napon belül PCI- vagy CABG-ke- zelésben részesültek aránya az időszakban megduplázódott, 2009-ben már majd' a betegek fele részesült ilyen beavatkozásban (3. táblázat).

Az időszakban mind a 90 napot, mind a 365 napot megélő betegek körében mérsékelten emelkedett és 8590\%-ot ért el a statint kiváltó betegek aránya. Hasonlóan magas az ACE-gátlók, illetve ARB-csoportba tartozó szereket vásárlók aránya. A béta-blokkolókat legalább egyszer kiváltók aránya csökkenő tendenciát mutat, a kezdeti 90\% körüli értékek után 2009-ben 67,0, illetve 75,6\%-ot mértünk (1. ábra).

A béta-blokkolók elhagyása nőtt az elemzési időszakban, és azok részaránya is egyre nagyobb, akik sem az indexfelvétel előttt, sem utána nem váltottak ki ilyen ké-

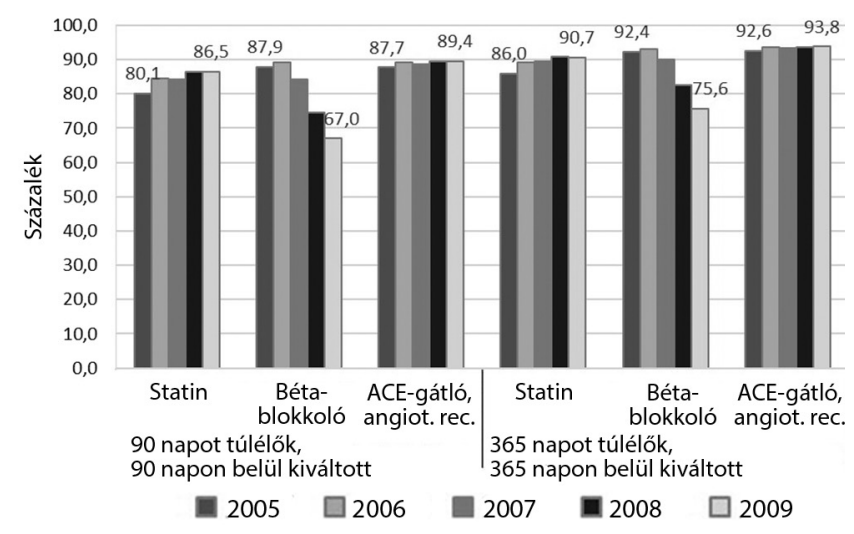

1. ábra $\quad$ AMI-betegek gyógyszerkiváltási aránya 2005-2009 között Magyarországon 


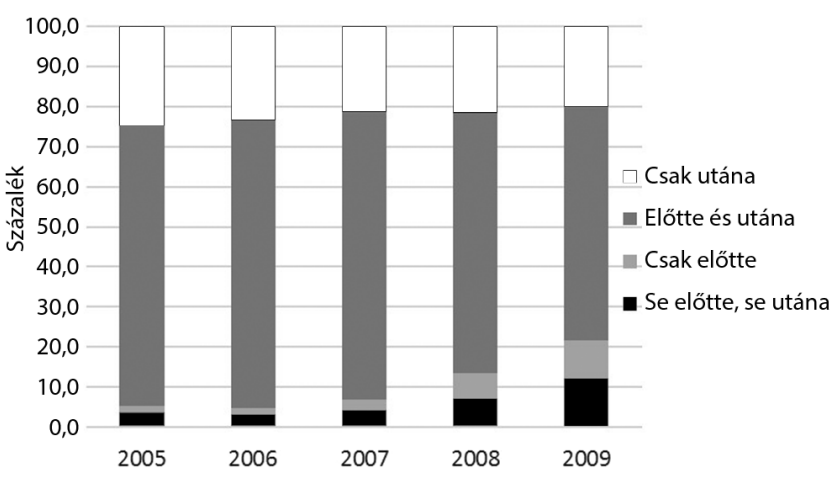

2. ábra

A béta-blokkolók kiváltásának megoszlása az indexfelvétel előtt és utána 365 napon belül a legalább 365 napot túlélt AMI-betegek körében Magyarországon, 2005-2009 között évente szítményt (2. ábra). A pontos értékeket nem tüntettük fel, mivel csak a kiváltás hónapját ismertük. Előfordulhatott, hogy egy hónap eleji felvételt követően a beteg még a hónap 15. napja elött váltott ki gyógyszert, ez az elemzési módszertan alapján az indexfelvétel előtt kiváltott kategóriába került. Mivel ez a torzítás minden évben azonos módon jelenik meg, a részarányok változása mindenképpen tükrözi a hazai tendenciát: csökken a bétablokkolók kiváltása, függetlenül attól, hogy a betegsége elött a beteg szedte-e (2. ábra).

A kockázatokra kiegyenlített halálozás mérsékelt javulást mutatott, az időszak elején a 30 napos halálozás $21,2 \%$, az időszak végén $18,8 \%$ volt, és hasonlóan, a 365 napos halálozás 31,7\%-ról 29,9\%-ra változott (3. táblá-

4. táblázat |A PCI-hez való hozzáférést és a halálozást befolyásoló tényezók kezelési csoportonként a hazai AMI-populációban, 2009

\begin{tabular}{|c|c|c|c|c|c|c|}
\hline \multirow[t]{2}{*}{ Vizsgált független változó ${ }^{+}$} & \multicolumn{2}{|c|}{ PCI két napon belül } & \multicolumn{2}{|c|}{$\begin{array}{l}7 \text { napon belüli halálozás korai } \\
\text { PCI-kezeltek között }\end{array}$} & \multicolumn{2}{|c|}{$\begin{array}{l}365 \text { napon belüli halálozás kései } \\
\text { PCI- vagy CABG-kezeltek között }\end{array}$} \\
\hline & Esélyhányados & Szignifikancia & Esélyhányados & Szignifikancia & Esélyhányados & Szignifikancia \\
\hline Férfi nem & 1,165 & $* * *$ & 0,746 & * & 1,194 & n. sz. \\
\hline \multicolumn{7}{|l|}{ 40-44 évesek } \\
\hline 45-49 évesek & 0,887 & n. sz. & 5,480 & n. sz. & 3,072 & n. sz. \\
\hline 50-54 évesek & 0,729 & n. sz. & 2,580 & n. sz. & 2,584 & n. sz. \\
\hline 55-59 évesek & 0,706 & ** & 9,212 & * & 4,433 & n. sz. \\
\hline 60-64 évesek & 0,534 & $* * *$ & 9,566 & * & 6,196 & n. sz. \\
\hline 65-69 évesek & 0,518 & $* * *$ & 15,281 & ** & 4,981 & n. sz. \\
\hline 70-74 évesek & 0,384 & $* * *$ & 17,941 & ** & 7,995 & n. sz. \\
\hline 75-79 évesek & 0,301 & $* * *$ & 19,601 & ** & 8,519 & * \\
\hline 80-84 évesek & 0,210 & $* * *$ & 55,263 & $* * *$ & 14,899 & ** \\
\hline Cukorbetegség & 0,884 & ** & 1,468 & * & 1,719 & ** \\
\hline Magas vérnyomás & 1,230 & $* * *$ & 0,326 & $* * *$ & 0,682 & n. sz. \\
\hline Coronariabetegség & 0,930 & n. sz. & 0,874 & n. sz. & 1,262 & n. sz. \\
\hline Stroke & 0,860 & n. sz. & 1,518 & n. sz. & 0,727 & n. sz. \\
\hline Pitvari fibrilláció & 0,755 & * & 1,013 & n. sz. & 0,971 & n. sz. \\
\hline Szívelégtelenség & 0,574 & $* * *$ & 1,522 & n. sz. & 1,150 & n. sz. \\
\hline Atherosclerosis & 0,740 & ** & 0,952 & n. sz. & 1,203 & n. sz. \\
\hline Daganat & 0,694 & ** & 1,227 & n. sz. & 1,200 & n. sz. \\
\hline COPD és asztma & 0,669 & $* * *$ & 1,062 & n. sz. & 1,331 & n. sz. \\
\hline Demencia & 0,328 & $* * *$ & 2,314 & n. sz. & 5,111 & * \\
\hline Depresszió & 0,974 & n. sz. & 1,047 & n. sz. & 1,125 & n. sz. \\
\hline Parkinson-kór & 0,750 & n. sz. & 1,393 & n. sz. & 1,765 & n. sz. \\
\hline Mentális betegségek & 0,466 & $* * *$ & 0,578 & n. sz. & 0,743 & n. sz. \\
\hline Alkoholizmus & 0,809 & n. sz. & 0,000 & n. sz. & 1,526 & n. sz. \\
\hline $\begin{array}{l}\text { Megelóző évben } \\
\text { kórházban töltött idő }\end{array}$ & 0,996 & ** & 1,003 & n. sz. & 1,011 & n. sz. \\
\hline Konstans & 1,903 & $* \star *$ & 0,008 & $* * *$ & 0,019 & $* * *$ \\
\hline
\end{tabular}

+Komorbiditás megelőző év kórházi felvételei és a gyógyszerkiváltások alapján.

${ }^{*} \mathrm{p}<0,05,{ }^{*} \mathrm{p}<0,01,{ }^{* *}{ }^{*} \mathrm{p}<0,001, \mathrm{n}$. sz: nem szignifikáns. 


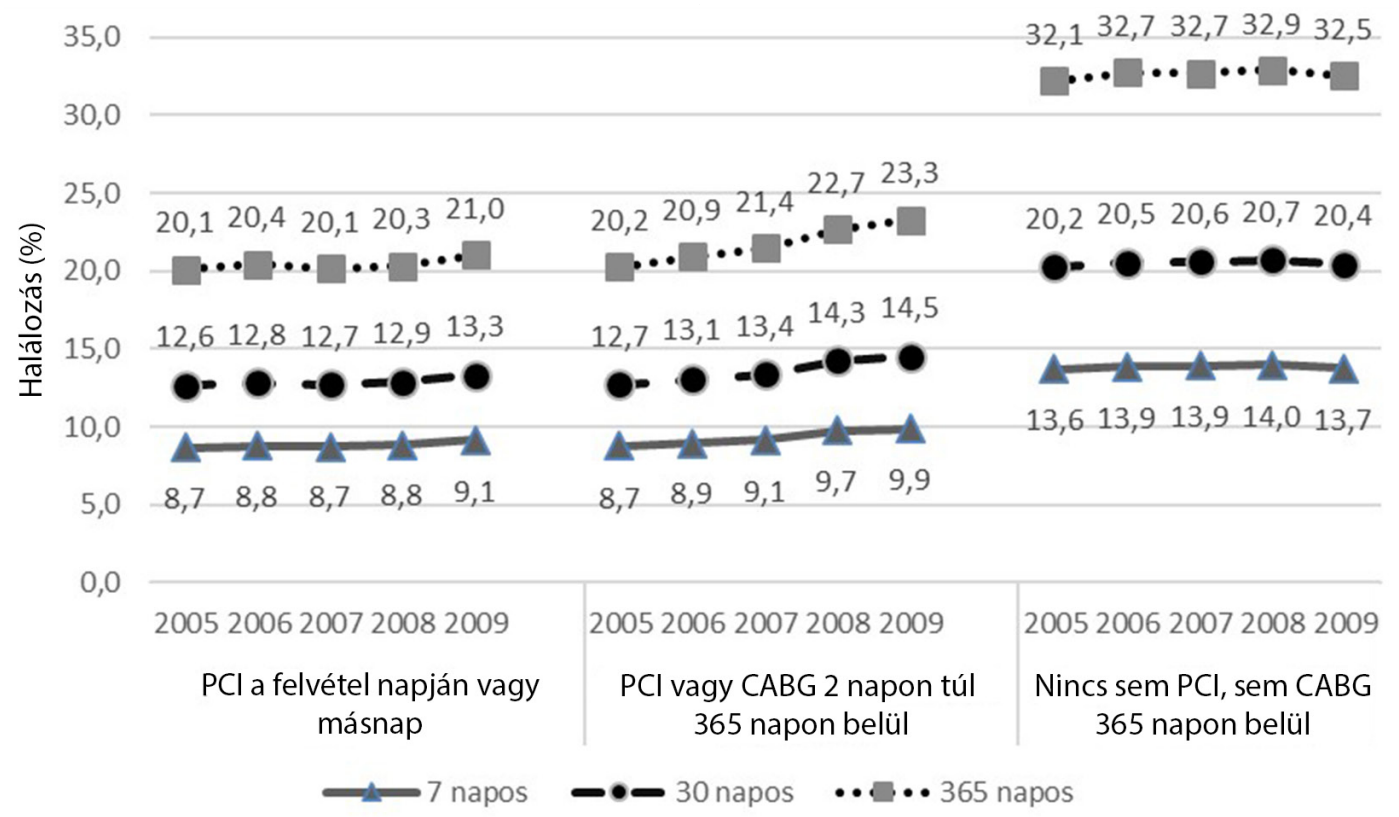

3. ábra

AMI-betegek kockázatra kiegyenlített* 7, 30 és 365 napos halálozása kezelési csoportok szerint, 2005-2009 között évente Magyarországon
*Kor, nem, gyógyszerkiváltással figyelembe vett kísérő betegségek szerint

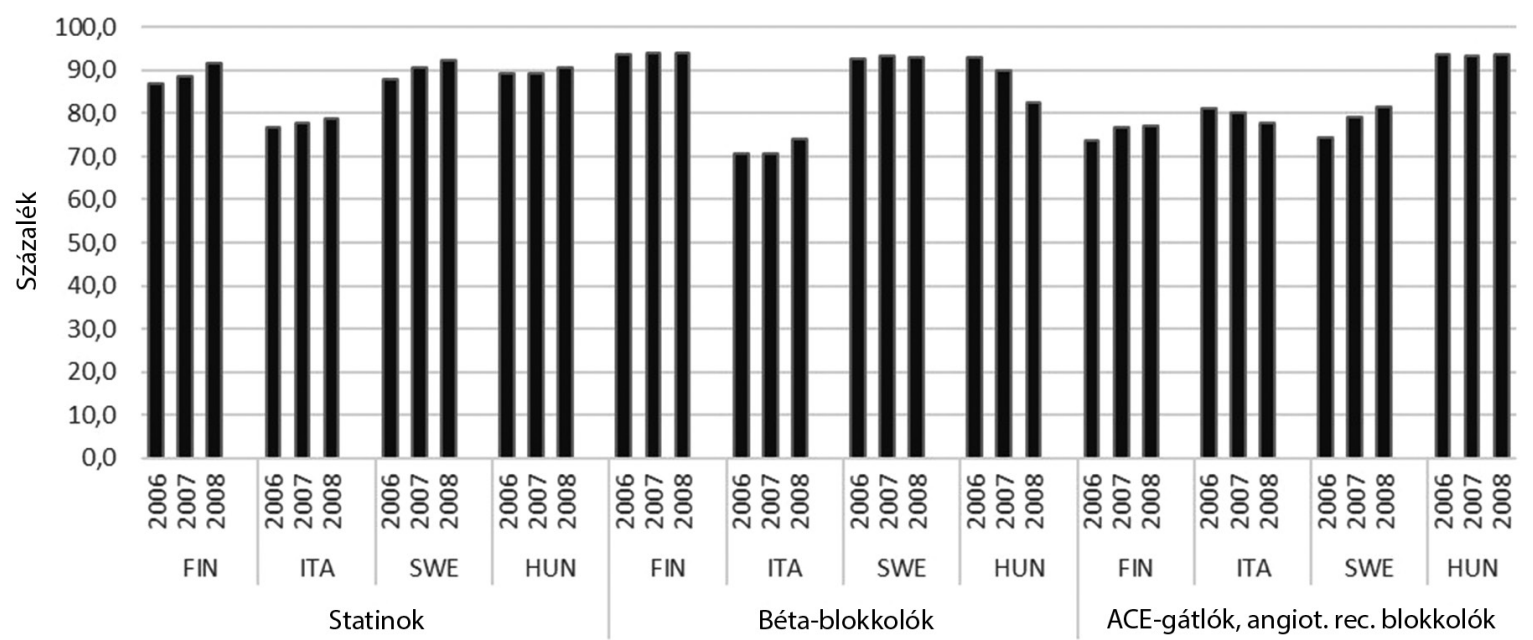

\begin{tabular}{l|l} 
4. ábra & AMI-betegek 365 napon belül kiváltott gyógyszerei 2006-2008 között a 365 napot túlélők körében a EuroHOPE országaiban \\
FIN = Finnország; HUN = Magyarország; ITA = Olaszország (Torino és Lazio tartomány); SWE = Svédország
\end{tabular}

zat). A halálozások alakulását különböző időtávokban, intervenciós csoportok szerint is mértük. A korai PCIkezelésben részesült vagy CABG-mútéten átesett betegek halálozása mind a három elemzett időtávban mérsékelten nőtt. Jelentősebb az emelkedés a kései kezeltek körében, különösen az egyéves halálozás vonatkozásában. Nem változtak a halálozási arányszámok az intervenciós kezelésben nem részesültek esetében (3. ábra).

A 2009-es hazai adatokon elemeztük a korai intervencióhoz való hozzáférést befolyásoló tényezőket, illetve az ugyanezen betegek korai halálozásának, illetve a kései intervención átesett betegek egyéves halálozásának kockázati tényezőit. Megállapítható, hogy a korai interven- cióra a férfiaknak és a fiatalabb betegeknek van nagyobb esélye, továbbá azoknak, akiknek ismert magasvérnyomás-betegségük van. Az egyéb kísérő betegségek megléte, illetve a beteg kedvezőtlenebb egészségi állapotára utaló, korábbi kórházban töltött idő csökkentik a korai intervenciós kezelések megvalósulásának esélyét. A korai PCI-kezeltek 7 napon belüli halálozására nagyobb esélye van a nőknek, az idősebbeknek és a cukorbetegeknek, de kedvezőbb a túlélés a magasvérnyomás-betegek körében. A kései intervencióban részesültek körében az egyéves halálozás esélye a legidősebbek körében, cukorbetegség esetén és különösen demenciában magasabb (4. táblázat). 
Nemzetközi összehasonlításban 2008-ban a hazai PCI- vagy CABG-kezelésben részesült AMI-betegek aránya kiemelkedő volt, a svéd adatokhoz közelít, míg a halálozási mutatók lényegesen kedvezőtlenebbek (3. táblázat).

A kiváltott statinok és az ACE-gátlók, illetve ARBcsoportban hazánk a nemzetközi adatoknál kedvezőbb eredményeket mutat. A béta-blokkoló kiváltási gyakorisága csak Magyarországon mutat csökkenést (4. ábra).

Vizsgáltuk a halálozás alakulását kezelési csoportok szerint is. A két napon belül kezeltek csoportjában mind a 30, mind a 365 napos halálozás szignifikánsan magasabb, mint a második legmagasabb halálozást mutató Skóciában $(\mathrm{p}<0,05)$. A kései intervenciós csoportban az éves halálozás a második legrosszabb értéket mutató olasz adat kétszerese. Érdemes azt is észrevenni, hogy az egyéves halálozás mind a korai, mind a kései intervenciós csoportban kiemelkedően eltér a többi ország adatától (5. ábra)

\section{Megbeszélés}

Az ellátás adminisztratív adatokon alapuló elemzése megszokott gyakorlat hazánkban, külföldön és a különböző nemzetközi indikátorprogramokban. Alkalmazásuk olcsó, gyors és standard elemzési módszereket tesz lehetővé, azonban időről időre kételyek merülnek fel a forrásadatok validitásával kapcsolatban. A EuroHOPE kutatás eredményeinek megbeszélését ezért ennek a kérdésnek a taglalásával kezdjük.

$\mathrm{Az}$ adatok hitelességét két módszerrel lehet vizsgálni. Egyrészt mintavételes eljárással a regulárisan beküldött, úgynevezett adminisztratív adatok és a betegdokumentáció összevetésével, másrészt az adott kutatás és más hasonló, megbízhatónak tartott közlemények eredményeinek összehasonlításával.

Ismereteink szerint az AMI adminisztratív adatainak minőségére vonatkozó publikáció nem készült. Ajtay 2015-ben a stroke-betegek betegdokumentációját és az

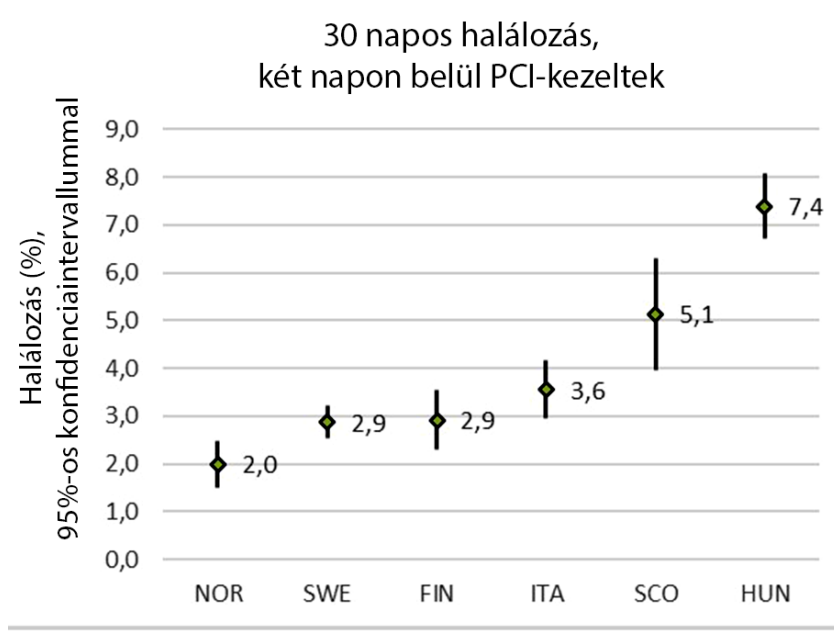

30 napos halálozás, két napon túl PCI/CABG kezeltek

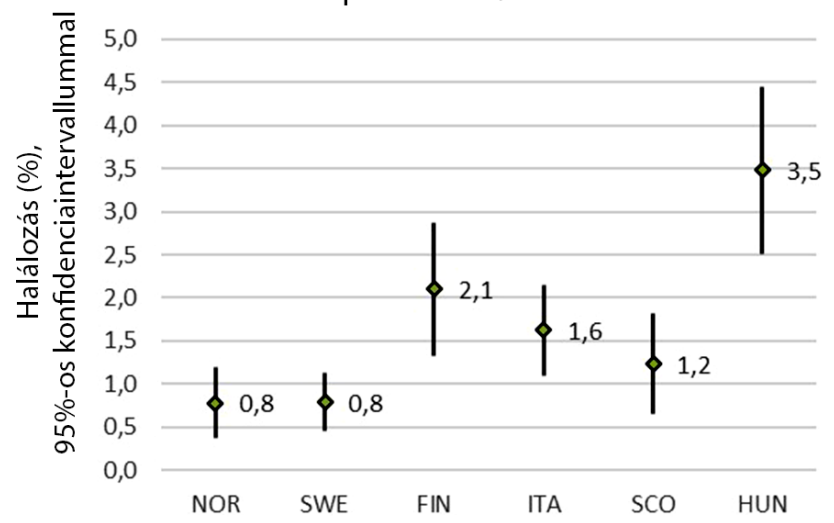

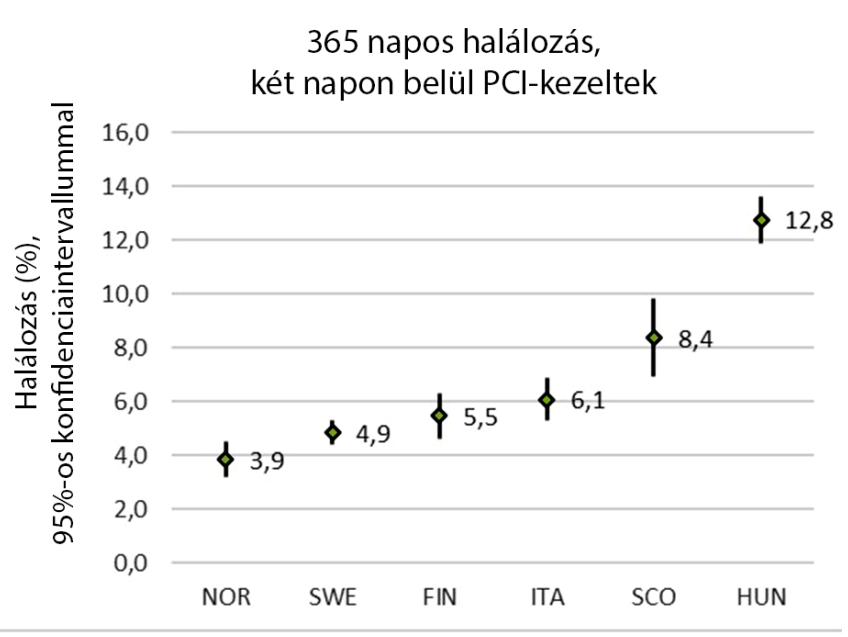

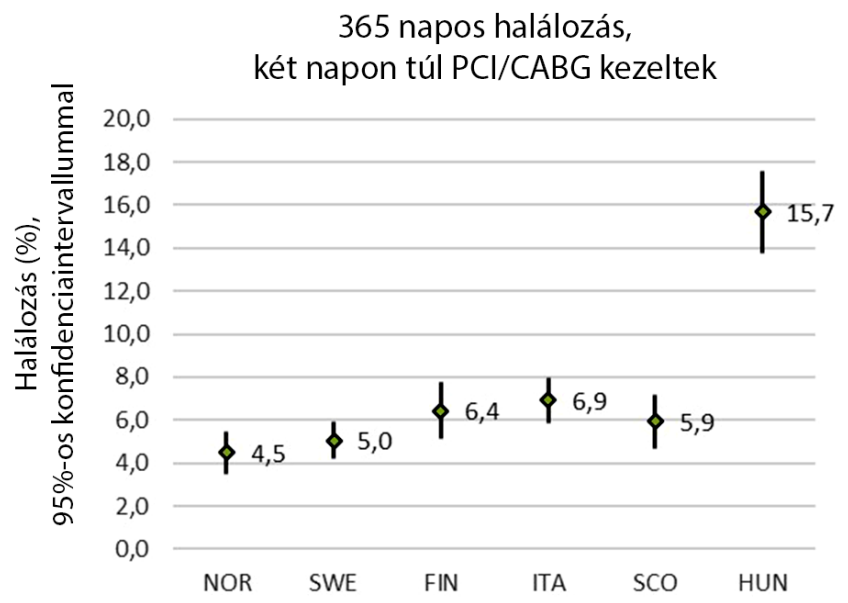

5. ábra AMI-betegek 30 és 365 napos kockázatokra* kiegyenlített halálozása kezelési csoportonként a EuroHOPE kutatás országaiban**, 2008***

*Kockázatra kiegyenlítés életkor, nem, ismert komorbiditás, előző évben kórházban töltött idő szerint.

* * FIN = Finnország; HUN = Magyarország; ITA = Olaszország (Torino és Lazio tartomány); NOR = Norvégia; SCO = Skócia; SWE = Svédország; ***Norvégia: 2009 . 
OEP-jelentéseket hasonlította össze. Eredményei szerint az OEP-adatok alkalmasak epidemiológiai elemzésekre, az ellátásszervezési változások következményeinek vizsgálatára, és jól elemezhető az egyes szakmák részvétele a különböző kórképek ellátásában [7]. Egy 2012-ben publikált tanulmány szerint az adminisztratív adatokból nyert AMI miatti kórházi felvételek szezonalitása megfelel a népegészségügyi kutatásokból ismert szezonális ingadozásnak [8]. Többváltozós elemzéseink szerint a férfiak nagyobb eséllyel részesülnek PCI-kezelésben, ami összhangban van a nemzetközi kutatásokkal [9]. Hasonlóan összecseng más publikált nemzetközi tanulmányok eredményével az a megfigyelésünk, amely szerint a PCIkezelés esélye alacsonyabb diabetes mellitusban, és ezen betegek halálozási esélye is magasabb [10]. Az a tény, hogy nemzetközi irodalomban publikált megfigyelések sora reprodukálható a hazai adminisztratív adatokból, megerôsíti alkalmazhatóságukat az AMI-populáció ellátásának elemzésében.

A PCI kezelésére vonatkozó ajánlás eltérő ST-elevációs (STEMI) és nem ST-elevációs (NSTEMI) myocardialis infarctus esetében. Míg STEMI-ben szoros időkeret mellett igazolt a PCI hatásossága, NSTEMI-nél az időkorlátok szabadabbak $[1,2]$. Tanulmányunkban nem volt lehetőség a STEMI- és NSTEMI-esetek elkülönítésére, mivel a részt vevő országoktól eltérően csupán Magyarországon nem alkalmaznak elkülönítő kódolást a két kórformára. Az adatforrások korlátai miatt nem volt lehetőség az intervencióig eltelt időt órában kifejezni.

Az általunk elemzett időszakban dinamikusan nőtt az invazív revascularisatiós kezelésekben részesült AMI-betegek aránya, és a kezelések időpontja egyre inkább eltolódott a korai intervenciók irányába. A két napon belüli kezelési gyakoriság nemzetközi összehasonlításban is kiemelkedő, csupán Svédország adatai mutattak némileg magasabb értéket. A magas arány a kardiológiai centrumokkal való kiváló ellátottságot tükrözi.

A kórházi távozást követően a gyógyszerek előírás szerinti szedése a túlélés szempontjából alapvető fontosságú $[1,2,11]$. A gyógyszeradatbázisok csak a patikában kiváltott gyógyszereket tartalmazzák, nincs információ arról, hogy ezt a betegek milyen dózisban és gyakorisággal szedik. A statinok és az ACE-gátlók, illetve ARB-k alkalmazási gyakorlata a vizsgált időszakban stabilan magas volt, és nemzetközi összehasonlításban is nagyon jó eredményt mutat. A béta-blokkolók alkalmazása az AMI-t követő időszakban viszont csökkent, amit nehéz megmagyarázni. Az kétségtelen, hogy diabetogén mellékhatásuk miatt egyre gyakrabban merül fel kétség alkalmazásuk tekintetében a hypertoniás populációban [12]. Az infarktust megelőző időszak csökkenő béta-blokkoló-alkalmazási gyakorisága ezért érthető is. A posztinfarktusos, illetve szívelégtelen populációban alkalmazásuk azonban továbbra is elvárható [2], a receptet kiváltók arányának csökkenése ezért nehezen értelmezhető.

A béta-blokkolók fogyasztási szerkezete jelentősen átalakult. A metoprololtartalmú készítmények alkalmazá- sa, a szakmai ajánlásokkal összhangban, jelentősen viszszaszorult a kedvezőbb mellékhatás-profilú, korszerú hatóanyagok javára. Ez összhangban áll a béta-blokkolók 2007-2014 közötti alkalmazásának elemzési eredményeivel [13].

A béta-blokkoló-felhasználás csökkenésének okait keresve elemeztük a gyógyszerár-támogatási rendszer változásait. A vizsgált időszakban került bevezetésre a terápiás fix elven múködő támogatási technika, illetve korábban több, normatív támogatással finanszírozott csoport esetében is hatóanyag-alapú fix támogatást vezettek be, amely bizonyos készítmények esetében a korábbi lakossági terhek jelentős emelkedéséhez vezethetett. Mivel azonban a béta-blokkolók mellett a statinok és ACE-gátlók, illetve ARB-k csoportjában is hasonló támogatási technikai változás következett be, így a bétablokkolók kiváltásának visszaesése a támogatási elvek módosulásával önállóan nem magyarázható. Nem lehet kizárni a feltörekvő új szerek, az egyre szélesebb körben alkalmazott ACE-gátlók, ARB-k kiszorító hatását, hiszen mindkét hatástani csoport vérnyomáscsökkenést eredményez, ami a kollégákat tévesen a béta-blokkolók elhagyására ösztönözheti.

Nemzetközi összehasonlításban mindhárom gyógyszer esetében Olaszországban találtuk a legalacsonyabb kiváltási arányt. Ez összefügghet a torinói eltérő gyógyszerfelírási szokásokkal, amely szerint a beteg kórházi távozásakor kézhez kapja háromhavi szedendő gyógyszeradagját. Mivel a helyes gyógyszerelés igazoltan javítja az AMI-betegek halálozási eredményeit [11], fontos annak tisztázása, miért csökkent a béta-blokkolók kiváltási gyakorisága, illetve szükséges a felhasználás alakulásának vizsgálata az elemzésünket követő időszakra vonatkozóan.

Az AMI-betegek 7 napos halálozása elsősorban a kórházi ellátás megfelelőségét tükrözi, a későbbi időpontokban bekövetkező halálozás növekvő mértékben függ az orvosi utasítások szakmai tartalmától és azok betartásától, a rehabilitációtól, illetve a beteg életmódjától, szociális környezetétől. A 7, 30 és 365 napos halálozást kezelési csoportok szerint vizsgáltuk. A korai és késői kezeltek kései halálozásának növekedése a kezeltek részarányának növekedésével magyarázható lehet, hiszen a kezeltek körének bővülésével egyre magasabb kockázati csoportba tartozó betegek is bekerültek az ellátotti körbe. Ezzel a logikával viszont figyelemre méltó a nem kezeltek halálozásának stabilitása, hiszen ebben a csoportban is logikus lenne a súlyosabb betegek koncentrálódása. A jelenség az egyre eredményesebb nem invazív kezelések, azaz a gyógyszerelés fontosságára hívja fel a figyelmet.

Nemzetközi összehasonlításban a magyarországi halálozás kiemelten a legrosszabb. A 365 napos halálozás legalább kétszerese a legjobb norvégénak, de a következő legrosszabb ország, Skócia adatainál is $25 \%$-kal magasabb értéket mutat. A korai intervenciós csoportban a többi országgal való összevetés még riasztóbb képet mutat, a 365 napos halálozás a norvég adat háromszorosa, 
a skóténak másfélszerese. A kései intervencióban részesültek esetében a magyarországi adatok még magasabbak a többi vizsgált országhoz képest.

Szakirodalmi közlések szerint elsősorban az idősek, magas kockázati csoportba tartozó betegek, illetve a PCI-kezelésben nem részesültek esetében az irányelvek követése kevésbé valósul meg [14-16]. Az intézményi menedzsment múködése fontos szereppel bír az AMIbetegek eredményes és hatékony ellátásában [17], így az irányelvek szerinti ellátás biztosítása is kiemelt jelentőségü $[11,18]$.

Az AMI-betegek halálozását az egészségügyi ellátás szakmai és múköodési gyakorlata mellett jelentősen befolyásolják a megbetegedés kapcsán a beteg életterében kialakult szociális változások is. Közismert, hogy minden tényező, amely a betegeket depresszív irányba tolja el, rontja túlélési esélyüket $[19,20]$. Mivel hazánkban mind a korai revascularisatiós arány, mind a gyógyszerelési arány a nyugat-európai átlagot meghaladó szinten volt, ez utóbbi tényező hatása mindenképpen felmerül. Az egészségügyi rendszer annyit tehet, hogy a szépen induló ellátási sort igyekszik szisztematikusan végigvinni, és a hatásos kezeléseket - ideértve a betegek fekvő, majd ambuláns rehabilitációs kezeléseit is - következetesen végigviszi.

\section{Következtetések}

Javasolt a szakmai munka és a múködési környezet szisztematikus elemzése mind a kórházi, mind az utána levó idôszakra kiterjedően a hazai magas halálozási viszonyok okainak feltárására. Javasolt továbbá a mélyebb elemzések elősegítése és a nemzetközi gyakorlathoz való igazodás a STEMI és NSTEMI kórformák elkülönítő kódolásának megvalósításával, a kórházi felvételek és a végzett beavatkozások pontos idő́pontjának megadásával. Javasolt az elemzések folytatása a trendek nyomon követése és a folyamatok mélyebb megértése érdekében.

Anyagi támogatás: A szerzők a közlemény alapját képező ismeretek összegyújtéséért az Európai Unió 7. keretprogramjának 241721. számú szerződése szerint a European Health Care Outcomes, Performance and Efficiency (EuroHOPE) projekt keretében anyagi támogatásban részesültek.

Szerzői munkamegosztás: B. É.: A közlemény vázának összeállítása, adatfeldolgozás, -elemzés, a kutatás hazai irányítása, a végleges változat elkészítése. L. J.: A gyógyszer-alkalmazási gyakorlat elemzése, az eredmények értelmezése. K. I.: Szakirodalmi áttekintés, a szakmai hangsúlyok kiemelése, az eredmények értelmezése, a következtetések megfogalmazása, a közlemény összeállítása. A cikk végleges változatát valamennyi szerző elolvasta és jóváhagyta.
Érdekeltségek: A szerző́k aktívan részt vettek a EuroHOPE kutatási projektben és a kutatás folytatásaként zajló BRIDGE projektben.

\section{Irodalom}

[1] Roffi, M., Patrono, C., Collet, J. P., et al.: 2015 ESC Guidelines for the management of acute coronary syndromes in patients presenting without persistent ST-segment elevation. Task Force for the Management of Acute Coronary Syndromes in Patients Presenting without Persistent ST-Segment Elevation of the European Society of Cardiology (ESC). Eur. Heart J., 2016, 37(3), 267-315.

[2] Steg, P. G., James, S. K., Atar, D., et al.: ESC Guidelines for the management of acute myocardial infarction in patients presenting with ST-segment elevation. The Task Force on the management of ST-segment elevation acute myocardial infarction of the European Society of Cardiology (ESC). Eur. Heart J., 2012, 33(20), 2569-2619.

[3] Lupkovics, G., Motyovszki, A., Németh, Z., et al.: Mortality rate of acute heart attack in Zalaegerszeg micro-region. Results of the first Hungarian 24-hour acute ST-elevation myocardial infarction intervention care unit. [A heveny szívinfarktus halálozásának alakulása Zalaegerszeg kistérségben. Az első magyarországi 24 órás ST-elevációs akut myocardialis infarctus intervenciós ügyelet hatásai.] Orv. Hetil., 2010, 151(14), 565-571. [Hungarian]

[4] Jánosi, A., Ofner, P., Branyickiné Géczy, G., et al.: Incidence of myocardial infarction in Hungary. Population study in five districts of Budapest and Szabolcs-Szatmár-Bereg county. [A szívinfarktus incidenciája Magyarországon. Epidemiológiai vizsgálat Budapest öt kerületében és Szabolcs-Szatmár-Bereg megyében.] Orv. Hetil., 2013, 154(28), 1106-1110. [Hungarian]

[5] Márk, L., Dani, Gy., Ruzsa, J., et al.: Has the length of prehospital time and diurnal fluctuation of the occurrence of AMI changed in the last 25 years in the catchment area of the hospital of Gyula? [Változott-e a szívinfarktus prehospitális ideje és kezdetének napszaki ingadozása az elmúlt negyed évszázadban a gyulai kórház ellátási területén?] Cardiologia Hung., 2015, 45(4), 253-257. [Hungarian]

[6] Jánosi, A., Ofner, P., Merkely, B., et al.: Short and long term prognosis of patients with myocardial infarction. Hungarian Myocardial Infarction Registry. [Szívinfarktus miatt kezelt betegek korai és késői prognózisa: Magyar Infarctus Regiszter Vizsgálat.] Orv. Hetil., 2013, 154(33), 1297-1302. [Hungarian]

[7] Ajtay, A., Oberfrank, F., Bereczki, D.: Applicability of hospital reports submitted for reimbursement purposes for epidemiological studies based on the example of ischemic cerebrovascular diseases. [A kórházi adatlapok jelentéseinek alkalmazhatósága epidemiológiai elemzésekre az ischaemiás cerebrovascularis betegségek példája alapján.] Orv. Hetil., 2015, 156(38), 15401546. [Hungarian]

[8] Belicza, É., Jánosi, A.: Study of incidence and treatment of acute myocardial infarction by evaluating the financing database: 2004-2009. [A heveny szívinfarktus előfordulásának és ellátásának vizsgálata a finanszírozási adatbázis elemzésével: 20042009.] Orv. Hetil., 2012, 153(3), 102-112. [Hungarian]

[9] Bugiardini, R., Yan, A. T., Yan, R. T., et al.: Factors influencing underutilization of evidence-based therapies in women. Eur. Heart J., 2011, 32(11), 1337-1344.

[10] Rousan, T. A., Pappy, R. M., Chen, A. Y., et al.: Impact of diabetes mellitus on clinical characteristics, management, and in-hospital outcomes in patients with acute myocardial infarction (from the NCDR). Am. J. Cardiol., 2014, 114(8), 1136-1144.

[11] Bramlage, P., Messer, C., Bitterlich, N., et al.: The effect of optimal medical therapy on 1-year mortality after acute myocardial infarction. Heart, 2010, 96(8), 604-609. 
[12] Fathallah, N., Slim, R., Larif, S., et al.: Drug-induced hyperglycaemia and diabetes. Drug Saf., 2015, 38(12), 1153-1168.

[13] Barna, I., Gyurcsányi, A.: The use of beta-blockers in Hungary 2007-2014 based on data from National Health Insurance. [A ß-blokkolók alkalmazása Magyarországon 2007-2014 között az OEP adatai alapján.] Hypertonia és Nephrologia, 2015, 19(3), 119-123. [Hungarian]

[14] Avezum, A., Makdisse, M., Spencer, F., et al.: Impact of age on management and outcome of acute coronary syndrome: Observations from the Global Registry of Acute Coronary Events (GRACE). Am. Heart J., 2005, 149(1), 67-73.

[15] Eagle, K. A., Goodman, S. G., Avezum, Á., et al.: Practice variation and missed opportunities for reperfusion in ST-segment elevation myocardial infarction: findings from the Global Registry of Acute Coronary Events (GRACE). Lancet, 2002, 359(9304), 373-377.

[16] Polonski, L., Gasior, M., Gierlotka, M., et al.: A comparison of ST elevation versus non-ST elevation myocardial infarction outcomes in a large registry database. Are non-ST myocardial infarctions associated with worse long-term prognoses? Int. J. Card., $2011,152(1), 70-77$.
[17] McConnell, K. J., Lindrooth, R. C., Wholey, D. R., et al.: Manage ment practices and the quality of care in cardiac units. JAMA Intern. Med., 2013, 173(8), 684-692.

[18] Kalla, K., Christ, G., Karnik, R., et al.: Implementation of guidelines improves the standard of care. The Viennese registry on reperfusion strategies in ST-elevation myocardial infarction (Vienna STEMI registry). Circulation, 2006, 113(20), 23982405.

[19] Denollet, J., Pedersen, S. S., Vrints, C. J., et al.: Predictive value of social inhibition and negative affectivity for cardiovascular events and mortality in patients with coronary artery disease: the type D personality construct. Psychosom. Med., 2013, 75(9), 873-881.

[20] Wu, Q., Kling, J. M.: Depression and the risk of myocardial infarction and coronary death: A meta-analysis of prospective cohort studies. Medicine (Baltimore), 2016, 95(6), e2815.

(Belicza Éva dr., Budapest, Kútvölgyi út 2., 1125 e-mail: belicza@emk.sote.hu)

\section{MEGHÍVó}

\section{A Szent János Kórház és Észak-budai Egyesített Kórházak Tudományos Bizottsága tisztelettel meghívja az érdeklődőket a következő tudományos ülésére.}

Időpont: 2016. október 20. (csütörtök) 14.00 óra Helyszín: Szent János Kórház Auditóriuma - 1125 Budapest, Diós árok 1-3.

\section{Téma: A felnőttkori krónikus betegségek gyermekkori vonatkozásai}

Üléselnök: Prof. Dr. Jánosi András

\section{Program:}

Dr. Blatniczky László: 2-es típusú diabetes (?) - metabolikus szindróma(?) gyermek-, ijúkorban

15 perc

Dr. Micskey Éva: Gyomorürülés megelőzése fiziológiás és afiziológiás állapotokban 15 perc

Dr. Madarasi Anna: A COPD gyermekkori vonatkozásai

Dr. Martyn Mária: Vesicoureteralis reflux prognózisát befolyásoló tényezök

Dr. Altmann Anna: latrogénián innen, terápián túl 